\title{
CHANGES IN THE CHEMICAL STRUCTURE OF THERMALLY TREATED WOOD
}

\author{
Ibrahim Tumen, ${ }^{\mathrm{a}}$ Deniz Aydemir, ${ }^{\mathrm{a}, *}$ Gokhan Gunduz, ${ }^{\mathrm{a}}$ Birol Uner, ${ }^{\mathrm{b}}$ and Hakan Cetin ${ }^{\mathrm{c}}$ \\ Changes in the chemical structure of hornbeam and uludag fir woods \\ during thermal treatment were investigated at three temperatures (170, \\ 190 , and $210^{\circ} \mathrm{C}$ ) and three durations (4, 8, and 12 hours). After thermal \\ treatment, the extents of degradation in the chemical structure of the \\ samples were determined, and the effects on the chemical composition of \\ hornbeam wood and uludag fir wood were investigated. The data \\ obtained were analyzed using variance analysis, and Tukey's test was \\ used to determine the changes in the chemical structure of uludag fir and \\ hornbeam woods. The results showed that heating wood permanently \\ changes several of its chemical structures and that the changes are \\ mainly caused by thermal degradation of wood polymers. It was found \\ that decreasing of the cellulose and holocelluloses ratio had a favorable \\ effect on the interaction of the wood with moisture. According to the \\ obtained results, hornbeam wood is affected more than uludag fir wood. \\ For each wood, the maximum decreases of holocellulose and a-cellulose \\ were found at $210^{\circ} \mathrm{C}$ for 12 hours, and the maximum increase of lignin \\ occurred at the same treatment combination.
}

Keywords: Uludag fir wood; Chemical structure; Cellulose; Lignin; Solubility

Contact information: a: Bartin University, Faculty of Forestry, Forest Industrial Engineering, Department of Wood Chemistry and Composite Materials, Agdacii Country, 74100, Bartin, Turkey; b: Suleyman Demirel University, Faculty of Forestry, Forest Industrial Engineering, Department of Wood Chemistry and Technology, 32100, Isparta, Turkey; c: Zonguldak Karaelmas University, School of Higher Education, Department of Furniture \& Design, Caycuma, 67230, Zonguldak, Turkey. *Corresponding author: denizoren32@yahoo.co.uk

\section{INTRODUCTION}

Wood can be degraded due to many reasons, including fungal activity, insects, and high humidity. Therefore, different methods have been developed to decrease this disadvantage for many years. One of these methods involves thermal treatments. Major research on this approach has been carried out to improve the physical properties of wood such as its moisture content and dimensional stability (Militz 2002; Gunduz and Aydemir, 2009; Gunduz et al., 2008; Kaygin et al. 2009a, b). Although physical properties improve, mechanical properties of wood decrease during thermal treatment at high temperatures (Poncsak et al. 2006; Gunduz and Aydemir 2009; Gunduz et al. 2009). When wood material is treated by heating, the chemical, physical, and mechanical properties of wood undergo permanent changes, and the structure of the wood is re-formed. The observed changes in the structure of wood can be mainly attributed to the degradation of hemicelluloses. These changes continue as the temperature is increasing during the heating process (Militz 2002).

During the thermal treatment, when wood material is heated slowly up to the range of 200 to $230^{\circ} \mathrm{C}$ in a humid inert gas, the chemical structure of wood changes, and all of its properties are affected (Raimo et al. 1996; Gailliot 1998). When wood material absorbs humidity from its surroundings, water molecules are inserted between and within the wood polymers (hemicelluloses and amorphous cellulose), hydrogen bonds are broken, 
and the bonds are re-formed (Hinterstoisser et al. 2003). The latter process creates crosslinks between wood fibers, and thus it significantly reduces the ability of the water to penetrate into the wood (Homan et al. 2000). Elimination of hydroxyl groups also reduces the number of potential anchoring points for fungi (Poncsak et al. 2006).

During the thermal treatment process, many volatile organic compounds such as alcohols, resins, terpenes, formic, and acidic acid are produced and released from the wood (Manninen et al. 2002; Graf et al. 2003). Significant decreases in hemicelluloses content also have been reported (Bekhta and Niemz 2003). The hemicelluloses degrade first (between 160 and $260^{\circ} \mathrm{C}$ ) since their low molecular weight and their branched structure facilitates a faster degradation compared to the other components present in wood (Fengel and Wegener 1984).

When the hemicelluloses are eliminated, the crystallinity of wood increases temporarily around 160 to $200^{\circ} \mathrm{C}$. At the end of the thermal treatment, the wood is abruptly cooled down with a spray of water. During this period, the extractives and other water soluble secondary substances with low molecular weights coming from the decomposition of various wood components are partially captured by water (Poncsak et al. 2006).

In earlier work the authors studied the effects of thermal treatment on physical, mechanical, and technological properties of various wood species (Gunduz et al. 2008, 2009b; Kaygin et al. 2009a). We now investigate hornbeam (Carpinus betulus L.) and uludag fir (Abies bornmulleriana Mattf.) woods with the aim of clarifying the changes in chemical structure caused by heat treatment. The changes induced in the structure of hornbeam and uludag fir woods by thermal treatment have not been reported extensively elsewhere.

\section{MATERIAL AND METHODS}

The hornbeam (Carpinus betulus L.) and uludag fir (Abies bornmulleriana Mattf.) wood samples used during this study were obtained from Bartin, Turkey. They had initial moisture contents that ranged from 11 to $13 \%$ before they were air dried. The dimensions of the samples were $20 \times 20 \times 30 \mathrm{~mm}$.

The test samples were thermally treated in an oven in which the temperature could be controlled to $\pm 1^{\circ} \mathrm{C}$. The treatments were conducted at three different temperatures $\left(170,190\right.$, and $\left.210^{\circ} \mathrm{C}\right)$ and for three different periods of time $(4,8$, and $12 \mathrm{~h})$ at atmospheric pressure in the presence of air. Before chemical analysis, thermal-treated and non-treated (control) wood samples were ground in a Wiley mill to a homogenous meal. This grinding was done according to TAPPI T257 cm-02. For the isolation of thermaltreated and non-treated wood extracts, extractives were dissolved in selected solvents, and the Soxhlet extraction process, which is highly efficient for this purpose because of alternate siphoning and filling of the extractor body with fresh solvent, was used. The material to be extracted was placed in a tall extraction thimble of glass with a round flask. As a result, wood material was isolated from the extractive materials, such as terpenes, stilbenes, flavonoids, and volatile compounds. A schematic overview of the chemical analyzing method used to determine the wood components, is given in Fig. 1.

Chemical analyses of the wood components were performed on non-treated and thermally treated uludag fir wood. The data obtained in the chemical analyses of the extracted wood particles were $\alpha$-cellulose content (TAPPI T212 om-02, 2002), holocellulose content (Wise and John 1952), lignin content (TAPPI T222 om-02, 2002), 
cold and hot water solubility, and 1\% NaOH solubility (TAPPI T207 cm-99, 1999). To determine the moisture content of the samples, the specimens were conditioned until their weights reached equilibrium; then they were weighed, and their equilibrium moisture contents (EMC) were calculated according to ISO 3130.

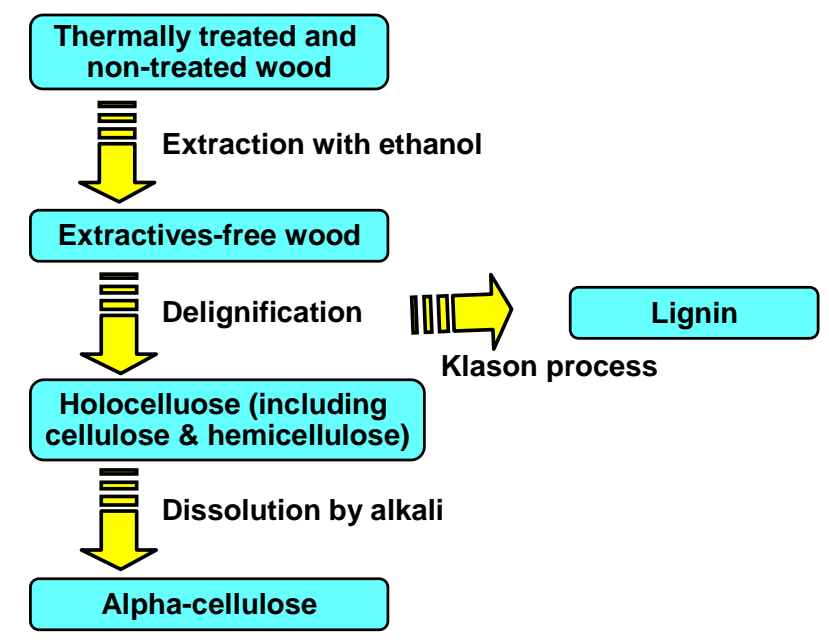

Figure 1. Chemical analysis of thermal-treated wood

\section{RESULTS AND DISCUSSION}

When wood is heated to temperatures of 160 to $250^{\circ} \mathrm{C}$, hemicelluloses start to degrade first, since they have the lowest molecular weight among the wood polymers. The degradation of the hemicelluloses results in a reduction of hydroxyl groups (-OH) and the formation of $\mathrm{O}$-acetyl groups. With the subsequent cross-link formation between the wood fibers, wood becomes more hydrophobic. Simultaneously, cellulose starts to degrade due to the formation of formic acid and acetic acid, and the lignin ratio increases due to the binding to lignin of separated substances from hemicelluloses and cellulose (Raimo et al. 1996; Gailliot 1998).

All statistical calculations for data obtained during the tests were based on a $95 \%$ confidence level. ANOVA and Tukey's Multiple Range Tests showed that all the reported differences were significant. Table 1 shows the influence of thermal treatment at different temperatures and durations on chemical properties, such as moisture content (\%), extractive content $(\%)$, holocellulose, $\alpha$-cellulose, lignin, cold water solubility, hot water solubility, and $1 \% \mathrm{NaOH}$ solubility as compared to control specimens.

Hornbeam and uludag fir woods contained about $8.5 \%$ and $8.1 \%$ moisture content and approximately $1.9 \%$ and $1.8 \%$ of volatile compounds. The moisture content of wood decreased due to evaporation during thermal treatment. But thermal treatment has a different effect on the mass content of extractives. According to Table 1, at first, the extractive mass content increased as treatment temperature and duration increased, but then it decreased when the temperature of the wood became high enough. It was determined that maximum and minimum ratio of extractive mass content were at $170^{\circ} \mathrm{C}$ for 4 hours and at $190^{\circ} \mathrm{C}$ for 4 hours for each type of wood. Uludag fir wood and hornbeam wood contains some volatile compounds that evaporate during thermal treatment. 
PEER-REVIEWED REVIEW ARTICLE

bioresources.com

Table 1. Changes in the Structure of Hornbeam and Uludag Fir Woods during Thermal Treatment

\begin{tabular}{|c|c|c|c|c|c|c|c|c|c|c|c|c|}
\hline \multirow{2}{*}{$\begin{array}{c}\text { Temperature } \\
\left({ }^{\circ} \mathrm{C}\right) \\
\end{array}$} & \multirow{2}{*}{$\begin{array}{l}\text { Duration } \\
\text { (hours) }\end{array}$} & \multirow{2}{*}{$\begin{array}{l}\text { Statistical } \\
\text { Values }\end{array}$} & \multicolumn{2}{|c|}{ Moisture (\%) } & \multicolumn{2}{|c|}{ Extractive Mass (\%) } & \multicolumn{2}{|c|}{ Holocellulose (\%) } & \multicolumn{2}{|c|}{ a-Cellulose (\%) } & \multicolumn{2}{|c|}{ Lignin (\%) } \\
\hline & & & Hornbeam & Fir & Hornbeam & Fir & Hornbeam & Fir & Hornbeam & Fir & Hornbeam & Fir \\
\hline \multirow{6}{*}{ Control } & & $x$ & 8.54 & 8.12 & 1.89 & 1.84 & 86.91 & 75.35 & 47.23 & 49.21 & 17.57 & 27.89 \\
\hline & & $\pm s$ & 0.06 & 0.50 & 0.03 & 0.29 & 0.21 & 1.07 & 0.64 & 2.06 & 0.31 & 1.07 \\
\hline & & $\mathrm{v} \%$ & 0.75 & 6.15 & 2.54 & 15.76 & 0.24 & 1.42 & 1.37 & 4.19 & 1.74 & 3.84 \\
\hline & & $x$ & 7.89 & 7.35 & 1.29 & 2.20 & 83.71 & 72.75 & 43.77 & 46.75 & 18.76 & 27.99 \\
\hline & 4 & $\pm s$ & 0.01 & 0.65 & 0.17 & 0.30 & 0.05 & 2.14 & 0.49 & 2.05 & 0.56 & 1.06 \\
\hline & & $\mathrm{v} \%$ & 0.12 & 11.30 & 2.8 & 13.64 & 0.06 & 2.94 & 1.12 & 4.39 & 2.97 & 3.79 \\
\hline \multirow{10}{*}{170} & & $x$ & 7.23 & 7.05 & 2.43 & 2.22 & 81.28 & 70.61 & 43.28 & 45.41 & 18.65 & 29.84 \\
\hline & 8 & $\pm s$ & 0.06 & 0.45 & 0.04 & 0.25 & 0.07 & 3.04 & 0.96 & 2.16 & 0.51 & 2.03 \\
\hline & & $\mathrm{v} \%$ & 0.78 & 6.38 & 0.66 & 11.26 & 0.08 & 4.31 & 2.22 & 4.76 & 2.71 & 6.80 \\
\hline & & $\mathrm{x}$ & 6.44 & 6.81 & 3.18 & 2.52 & 78.48 & 66.75 & 43.21 & 44.37 & 20.04 & 31.06 \\
\hline & 12 & $\pm s$ & 0.04 & 0.68 & 0.01 & 0.10 & 0.64 & 2.13 & 1.23 & 3.31 & 0.1 & 2.40 \\
\hline & & $\mathrm{v} \%$ & 0.66 & 9.99 & 0.29 & 3.97 & 0.81 & 3.19 & 2.84 & 7.46 & 0.48 & 7.73 \\
\hline & & $x$ & 5.75 & 7.14 & 3.21 & 2.30 & 73.01 & 68.52 & 41.71 & 44.89 & 19.06 & 31.69 \\
\hline & 4 & $\pm s$ & 0.07 & 0.78 & 0.29 & 0.19 & 0.03 & 2.60 & 1.59 & 1.66 & 0.26 & 1.55 \\
\hline & & $\mathrm{v} \%$ & 1.23 & 10.92 & 9.87 & 8.26 & 0.04 & 3.79 & 3.81 & 3.70 & 1.35 & 4.89 \\
\hline & & $x$ & 5.61 & 6.91 & 4.41 & 2.48 & 69.13 & 60.20 & 38.95 & 41.72 & 19.42 & 34.69 \\
\hline \multirow[t]{9}{*}{190} & 8 & $\pm \mathrm{s}$ & 0.09 & 0.65 & 0.1 & 0.32 & 0.52 & 2.95 & 1 & 1.96 & 0.54 & 1.63 \\
\hline & & $\mathrm{v} \%$ & 1.64 & 9.41 & 2.5 & 12.90 & 0.76 & 4.90 & 2.57 & 4.70 & 2.79 & 4.70 \\
\hline & & $x$ & 5.29 & 6.28 & 5.07 & 2.77 & 65.29 & 61.19 & 34.47 & 39.30 & 21.8 & 34.08 \\
\hline & 12 & $\pm s$ & 0.03 & 0.45 & 0.26 & 0.13 & 0.15 & 2.55 & 1.92 & 1.68 & 1.13 & 1.55 \\
\hline & & $\mathrm{v} \%$ & 0.53 & 7.17 & 5.7 & 4.69 & 0.23 & 4.17 & 5.58 & 4.27 & 5.18 & 4.55 \\
\hline & & $x$ & 6.81 & 6.88 & 5.14 & 2.60 & 67.11 & 57.61 & 36 & 37.21 & 25.04 & 41.11 \\
\hline & 4 & $\pm s$ & 0.01 & 0.34 & 0.2 & 0.30 & 0.14 & 2.77 & 1.21 & 2.14 & 0.4 & 1.75 \\
\hline & & $\mathrm{v} \%$ & 0.1 & 4.94 & 5.18 & 11.54 & 0.21 & 4.81 & 3.37 & 5.75 & 1.6 & 4.26 \\
\hline & & $x$ & 5.14 & 5.54 & 4.74 & 2.61 & 65.33 & 53.34 & 28.7 & 35.36 & 31.86 & 41.42 \\
\hline \multirow[t]{5}{*}{210} & 8 & $\pm s$ & 0.04 & 0.46 & 0.68 & 0.30 & 0.17 & 1.52 & 3.07 & 2.35 & 0.38 & 1.77 \\
\hline & & $\mathrm{v} \%$ & 0.83 & 8.30 & 18.18 & 11.49 & 0.26 & 2.85 & 10.7 & 6.65 & 1.19 & 4.27 \\
\hline & & $x$ & 5.48 & 5.52 & 4.44 & 2.56 & 66.39 & 58.05 & 24.73 & 36.43 & 32.71 & 43.14 \\
\hline & 12 & $\pm s$ & 0.03 & 0.57 & 0.01 & 0.40 & 1.02 & 3.01 & 1.9 & 2.64 & 0.27 & 1.95 \\
\hline & & $\mathrm{v} \%$ & 0.46 & 10.33 & 0.27 & 15.63 & 1.53 & 5.19 & 7.68 & 7.25 & 0.81 & 4.52 \\
\hline
\end{tabular}

$\overline{\mathrm{X}, \pm \mathrm{S} \text { and } \mathrm{v}(\%)}$ show average, standard deviation and variation coefficient, 
During thermal treatment, it was found that the mass ratios of the basic components (hemicellulose, lignin, and cellulose) of uludağ fir wood were changed. As the treatment temperatures were increased, hemicellulose and cellulose began to degrade and their ratios began to decrease. But cellulose amounts were not significantly changed until $180^{\circ} \mathrm{C}$ for 8 hours. Lignin starts to degrade at a temperature of $206{ }^{\circ} \mathrm{C}$. During thermal treatment, holocellulose and especially cellulose after $200^{\circ} \mathrm{C}$ started to degrade fast. Lignin ratio was also increased monotonically at the begining of the thermal treatment process, and after $200^{\circ} \mathrm{C}$ the lignin ratio increased significantly. It is hypothesized that the increase in the proportion of lignin in the sample was caused by degradation of holocellulose and cellulose. It also was determined that the increase in lignin occured in parallel to the decreasing cellulose and hemicellulose ratios (Fig. 1). The maximum increase in the lignin ratio of $34.8 \%$ occurred at $200{ }^{\circ} \mathrm{C}$ for 8 hours, while the lowest increase in the lignin ratio of only $6.4 \%$ occurred at $170{ }^{\circ} \mathrm{C}$ for 4 hours.

Lignin is the most stable component of wood during thermal treatment; whereas various changes were observed even at temperatures below $200^{\circ} \mathrm{C}$. The determination of the lignin content in thermally treated wood gave evidence of an increase in nonhydrolysable residue with increasing temperature up to $200^{\circ} \mathrm{C}$. Regarding the degree and shape of fiber swelling as criteria of thermally caused changes, researchers have found no change in lignin up to $155^{\circ} \mathrm{C}$. Heating at $175^{\circ} \mathrm{C}$ caused a lignin condensation that increased with temperatures up to $240^{\circ} \mathrm{C}$ (Fengel and Wegener 1989).

The changing ratios of the cellulose, hemicelluloses, and lignin content determination are shown in Fig 2. The cellulose contents of thermally treated wood samples decreased in comparison to the control wood. This decrease was greater in the case of hornbeam than uludag fir as thermal temperature and duration were increased. After thermal treatment, the largest and lowest changing of cellulose content in all thermal treatment was found at $170^{\circ} \mathrm{C}$ for 4 hours and $210^{\circ} \mathrm{C}$ for 12 hours for each wood respectively.

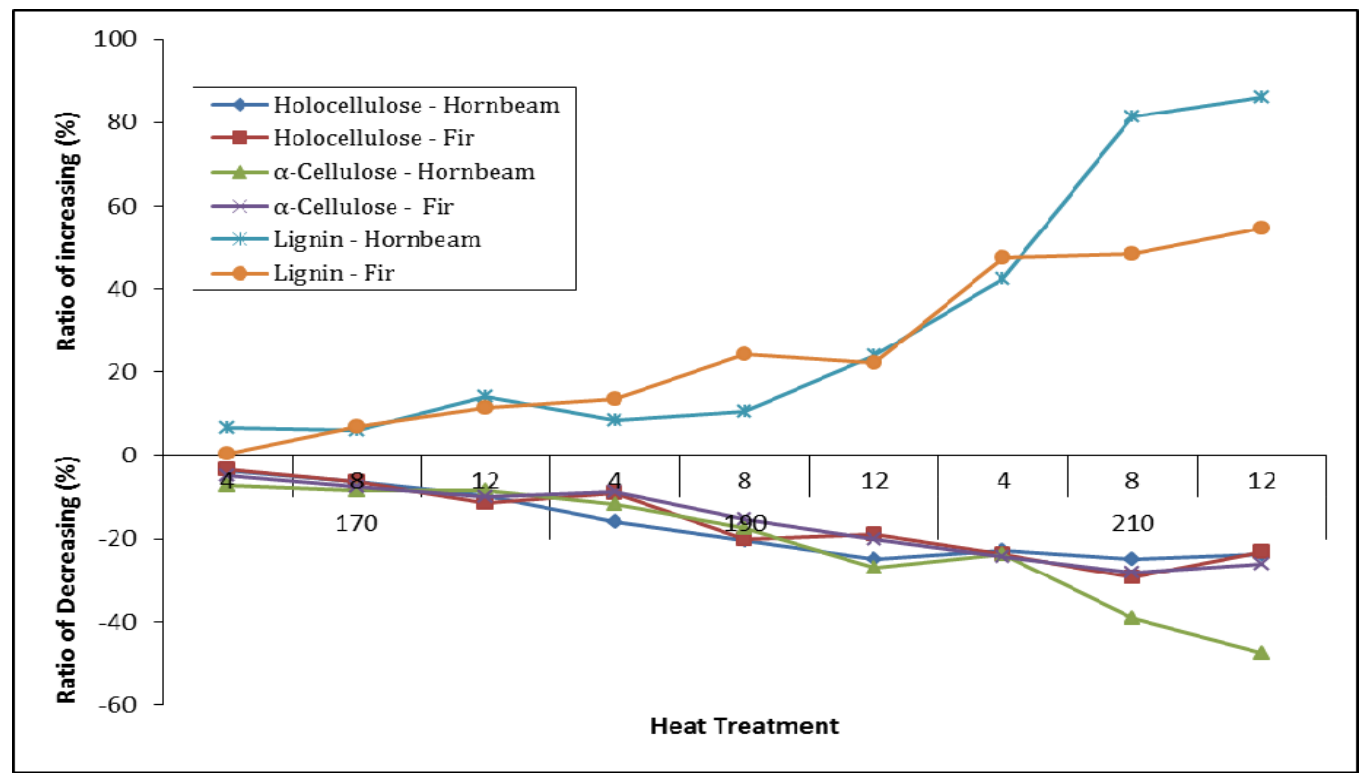

Figure 2. The changes in chemical structure of heat-treated wood 
According to the thermogravimetric analysis the first change observed in the heating of cellulose, which occurs at about $100{ }^{\circ} \mathrm{C}$, is the elimination of adsorbed water (Kotilainen 2000).

By raising the temperature above $200^{\circ} \mathrm{C}$ the thermal degradation of cellulose and formation of volatile products proceeds rapidly. Levoglucosan is frequently said to be the most important primary degradation product, but other anhydroglucoses, furan, and furan derivatives are also produced (Manninen 2002; Fengel and Wegener 1989).

Hemicelluloses values exhibited a significant decrease as treatment temperature and duration were increased. Reduction of hemicelluloses content was found to be higher as compared to cellulose content. Dramatic reductions in the contents of hemicelluloses started at temperature and duration above $180^{\circ} \mathrm{C}$ for $6 \mathrm{~h}$. Due to structural heterogeneity of hemicelluloses, it is a complex matter to reveal their thermal behavior. Xylan (pentosan) is the most reactive wood hemicelluloses, and in general pentosans are very sensitive to degradation and dehydration reactions (Kotilainen 2000; Manninen et al. 2002).

The most intensive thermal degradation takes place in the temperature range of 200 to $260^{\circ} \mathrm{C}$. The lower thermal stability of hemicelluloses compared to cellulose is usually explained by the lack of crystallinity. In addition, more gaseous products and less charred residue are formed in the pyrolysis of hemicelluloses than that of cellulose (Kotilainen 2000).

Lignin values increased with an increase in treatment temperature and duration. The highest lignin contents were obtained from the most severe treatment conditions at $210^{\circ} \mathrm{C}$ for $8 \mathrm{~h}(31.86 \%)$ and $210^{\circ} \mathrm{C}$ for $12 \mathrm{~h}(32.71 \%)$. This result confirmed most of the conclusions reported in the literature (Kotilainen 2000; Yildiz 2006).

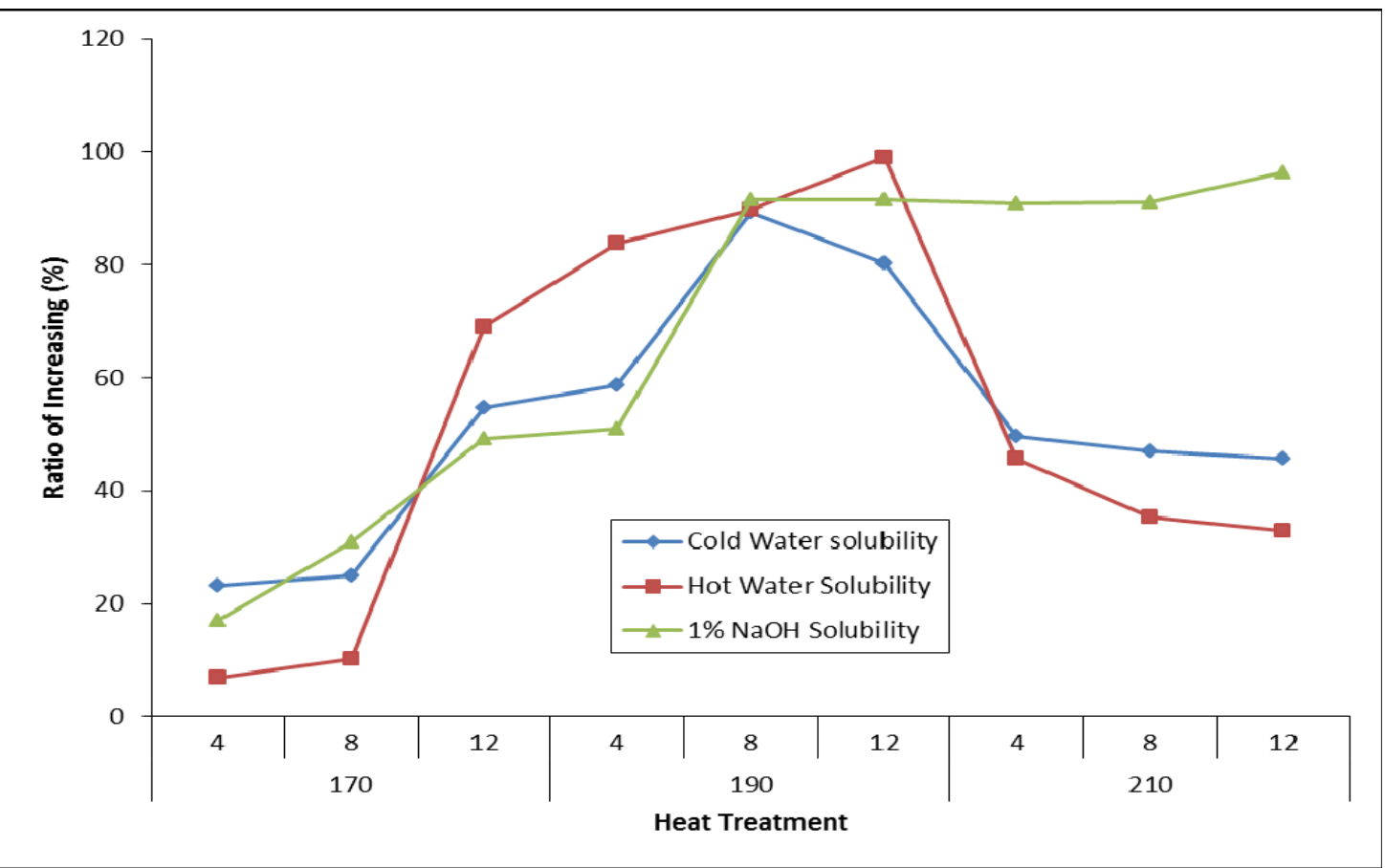

Figure 3. Changes in solubility of heat-treated hornbeam wood 


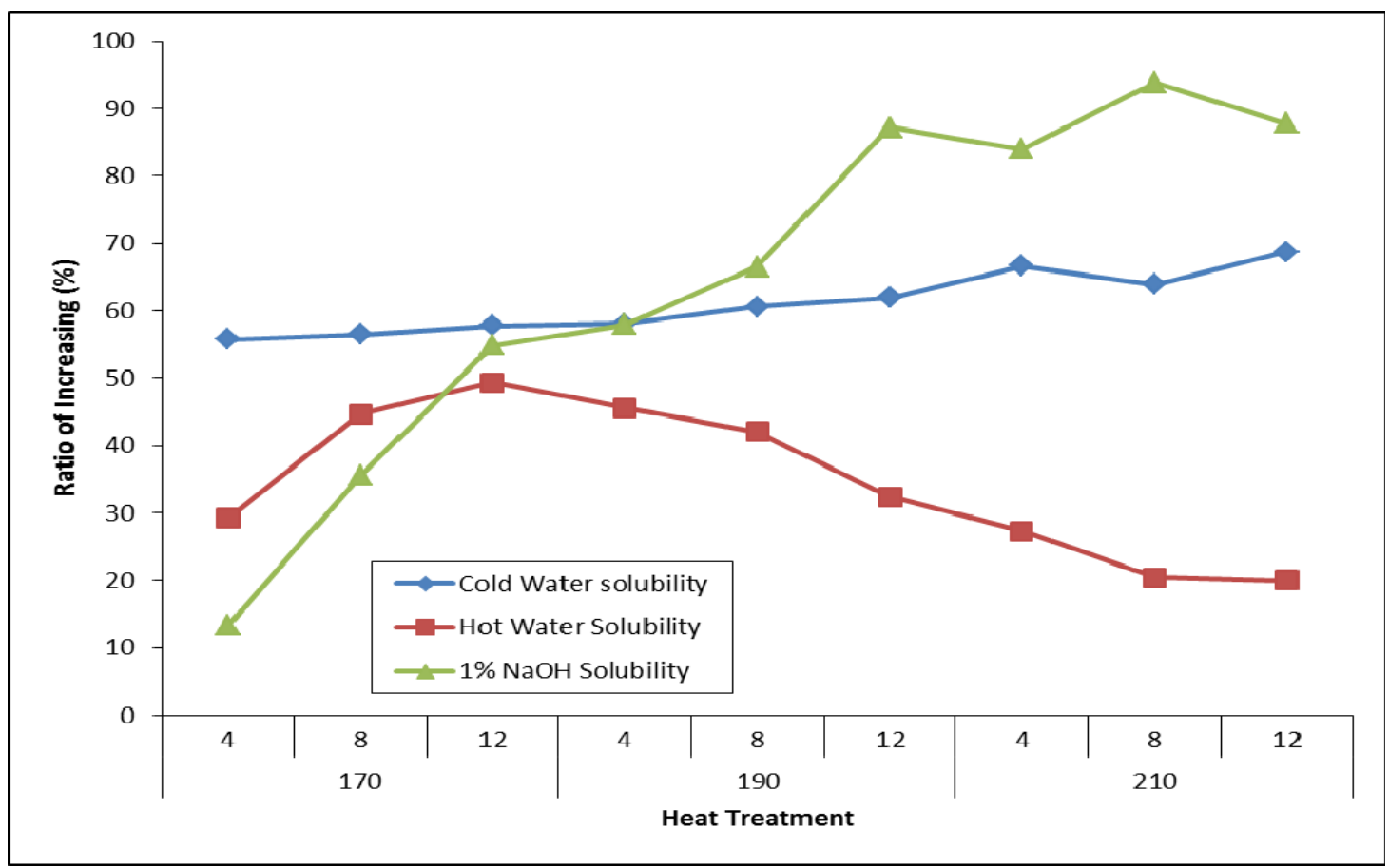

Figure 4. Changes in solubility of heat-treated fir wood

According to Figs. 3 and 4, the cold and hot water solubilities (\%) were increased at test conditions of $170{ }^{\circ} \mathrm{C}$ for 8 hours and $190{ }^{\circ} \mathrm{C}$ for 12 hours, but they were decreased when the test conditions were $210{ }^{\circ} \mathrm{C}$ for 4 and 8 hours. This reversal was not observed for solubility in a $1 \% \mathrm{NaOH}$ solution, as the solubility of uludag fir wood was observed to increase consistently as treatment temperatures and durations increased. It can be said that these changes in the solubility of uludag fir wood occurred because of the thermal degradation of wood, particularly hemicellulose, because it has more hydroxyl groups.

The increase in the concentration of the soluble fraction in the treated product is attributable to depolymerization of the components of the cell wall during thermal treatment. The water-soluble fraction increased to a greater extent than the non-polar fraction. This indicates a depolymerization of the carbohydrate, especially of the hemicelluloses. A higher treatment temperature during the hydro-thermolysis appears to have an effect on the concentration of the soluble fraction, due to the formation of furfural and/or some degradation products of the lignin component of wood (Boonstra and Tjeerdsma 2006).

\section{CONCLUSIONS}

In this study, hornbeam and uludag fir woods were exposed to thermal treatment at 170,190 , and $210^{\circ} \mathrm{C}$ for periods of 4,8 , and 12 hours. Since holocellulose was the main polymer component in the wood, it was degraded by 3.4 to $22.9 \%$ for hornbeam; approximately 3.7 to $23.6 \%$ for hornbeam wood, and $\alpha$-cellulose was degraded by 7.3 to $47.6 \%$, depending on the treatment conditions. The ratio of lignin was increased within the range $6.7 \%$ to 86.16 for hornbeam and within the range $0.35 \%$ to $54.67 \%$ for 
hornbeam. Moreover, the moisture content of the wood decreased by 7.6 to $35.8 \%$ for hornbeam and $9.4 \%$ to $32.01 \%$ for uludag fir, because of the degradation of the hydroxyl groups of $\alpha$-cellulose and the hemicelluloses. Besides, the fragments that were broken down from cellulose and hemicelluloses connected easily with lignin, causing an increase in the lignin ratio in the wood. Because lignin is a hydrophobic material, the moisture content was decreased. Because of the reasons mentioned above, thermally treated uludag fir wood can be used in saunas, pool edges, wood siding, ship decks, and garden furniture. Holocellulose, which is a connecting component in wood, breaks down during heat treatment. Therefore, heat treatment causes mass loss, and the resulting material can be significantly lighter in weight than the original wood, making it useful for insulation, the parquet flooring industry, and for decorative purposes.

\section{REFERENCES CITED}

Bekhta, P., and Niemz, P. (2003). "Effect of high temperature on the change in color, dimensional stability and mechanical properties of spruce wood," Holzforschung 57 (5), 539-546.

Boonstra, M. J. L, and Tjeerdsma, B. (2006). "Chemical analysis of heat treated softwoods," Holz als Roh- und Werkstoff 64, 204-211.

Fengel, D., and Wegener, G. (1989). Wood: Chemistry, Ultrastructure, Reactions, Walter de Gruyter 33, 333-335.

Gailliot, F. P. (1998). Extraction and Product Capture in Natural Product Isolation, Cannell. Humana Press, Totowa, pp. 59-68.

Graf, N., Haas, W., and Bochzelt, H. (2003). "Characterization of gaseous emission from a small-size industrial plant for thermal wood modification by GC/MS," In: van Acker, J., and Hill, C. (eds.), The 1st European Conference on Wood Modification, Proceeding of the First International Conference of the European Society for Wood Mechanics, April 2nd to 4th 2003, Ghent, Belgium, ISBN 9080656526, pp. 55-58.

Gunduz, G., and Aydemir, D. (2009). "Some physical properties of heat-treated hornbeam (Carpinus betulus L.) wood," Drying Technology 27(5), 714-720.

Gunduz, G., Aydemir, D., and Karakas, G. (2009). "The effects of thermal treatment on the mechanical properties of wild Pear (Pyrus elaeagnifolia Pall.) wood and changes in physical properties," Materials and Design 30(10), 4391-4395.

Gunduz, G., Niemz, P., and Aydemir, D. (2008). "Changes in specific gravity and equilibrium moisture content in heat-treated fir (Abies nordmanniana subsp. bornmulleriana Mattf.) wood," Drying Technology 26(9), 1135-1139.

Hinterstoisser, B., Schwanninger, M., Stefke, B., Stingl, R., and Patzelt, M. (2003). "Surface analyses of chemically and thermally modified wood by FT-NIR," In: van Acker, J., and Hill, C. (eds.), The 1st European Conference on Wood Modification, Proceeding of the First International Conference of the European Society for Wood Mechanics, April 2nd to 4th, Ghent, Belgium, ISBN 9080656526, pp. 65-70.

Homan, W., Tjeerdsma, B., Beckers, E., and Joressen A. (2000). "Structural and other properties of modified wood," Congress WCTE, Whistler, Canada, pp. 3.5.1-1-3.5.18. 
ISO 3130. (1975). "Wood - Determination of moisture content for physical and mechanical tests," Geneva, Switzerland.

Kaygin, B., Gunduz, G., and Aydemir, D. (2009a). "Some physical properties of heattreated paulownia (Paulownia elongata) wood," Drying Technology 27(1), 89-93.

Kaygin, B., Gunduz, G., and Aydemir, D. (2009b). "The effect of mass loss on mechanic properties of heat treated paulownia (Paulownia elongata) wood," Wood Research 54(2), 101-108.

Kotilainen, R. (2000). "Chemical changes in wood during heating at 150-260 ${ }^{\circ} \mathrm{C}$," $\mathrm{Ph} . \mathrm{D}$. thesis, Jyvaskyla University, Research report 80, Finland.

Manninen, A. M., Pasanen, P., and Holopainen, J. K. (2002). "Comparing the VOC emission between air-dried and heat treated Scots pine wood," Atmos. Environ. 36, 1763-1768.

Militz, H. (2002). "Heat treatment technologies in Europe: Scientific background and technological state of art," In: Proceedings of conference-enhancing the durability of lumber and engineered wood products, Forest Product Society, Kissimmee, Orlando, Madison, USA.

Poncsak, S., Kocaefe, D., Bouazara, M., and Pichette, M. (2005). "Effect of high temperature treatment on the mechanical properties of birch (Betula papyrifera)," Wood Science and Technology 66(1), 39-49.

Raimo, A., Kuoppala, E., and Oesch, P. (1996). "Formation of the main degradation compounds groups from wood and its components during pyrolysis," J. Anal. Appl. Pyrolysis 36, 137-148.

TAPPI T207 cm-99. (1999). "Water solubility of wood and pulp," TAPPI, Altanta, US.

TAPPI T212 om-02. (2002). "One percent sodium hydroxide solubility of wood and pulp," TAPPI, Altanta, US.

TAPPI T222 om-02. (2002). “Acid-insoluble lignin in wood and pulp,” TAPPI, Atlanta, US.

TAPPI T257 cm-02. (2002). "Sampling and preparing wood for chemical analysis," TAPPI, Atlanta, US.

Wise, L. E., and John, E. C. (1952). Wood Chemistry. Ed. 2, Vol. 1 \& 2, Reinhold Publication Co., New York, US.

Yıldız, S., Gezer, E. G., and Y1ldız, Ü. C. (2006). "Mechanical and chemical behavior of spruce wood modified by heat," Building and Environment 41(12), 1762-1766.

Article submitted: May 1, 2010; Peer review completed: July 13, 2010; Revised version received and accepted: July 26, 2010; Published July 28, 2010. 